\title{
Kurumsal Risk Yönetimi Olgunlaşma Seviyesinin Finansal Performansa Etkisi: Türkiye Örneği*
}

\begin{abstract}
Yasemin ERTAN**
Aylin POROY ARSOY***

Tuba BORA KILINÇARSLAN ${ }^{* * * *}$

\section{ÖZET}

1990 'l y yllarda yaşanan bazı şirket skandalları risk yönetimine verilen önemin artmasına neden olmuş ve risk yönetimi faaliyetlerinin bütünleşik bir yaklaşımla uygulanmasının gerektiğini göstermiştir. Risk yönetiminde uygulanan bütünleşik yaklaşım, kurumsal risk yönetimi olarak ifade edilmektedir. Bu çalışmanın amacı, Borsa İstanbul'da işlem gören imalat işletmelerinin kurumsal risk yönetimi olgunlaşma seviyelerinin, finansal performanslart üzerindeki etkisini incelemektir. Araştırmanın sonuçları, işletmelerin kurumsal risk yönetimi olgunlaşma seviyeleri ile varlık karlılıkları ve özsermaye karlılıkları arasında istatistiki olarak anlamlı ve pozitif bir ilişkinin olduğunu ortaya koymaktadır. karlılı̆̆ı.

Anahtar Kelimeler: Kurumsal risk yönetimi, finansal performans, aktif karlılığı, özsermaye

JEL Siniflandirması: M41, M49, G32.
\end{abstract}

\section{The Effect of Enterprise Risk Management Maturity Level on Financial} Performance: The Turkish Case

\section{ABSTRACT}

Some Corporate failures in 1990s have increased the importance of risk management and revealed that risk management activities must be maintained with integrated perspective. Integrated perspective in risk management is expressed as enterprise risk management. The aim of this study is to investigate the effect of Enterprise Risk Management Maturity Level of manufacturing companies listed on Borsa Istanbul on their financial performance. The results show that there is a significant positive relationship between Enterprise Risk Management Maturity Level and return on assets and between Enterprise Risk Management Maturity Level and return on equity.

Keywords: Enterprise risk management, financial performance, return on assets, return on equity.

Jel Classification: M41, M49, G32.

\footnotetext{
* Bu çalışma Uludağ Üniversitesi Bilimsel Araştırma Projeleri tarafından desteklenen KUAP(İ)-2015-75 Nolu ve "Kurumsal Risk Yönetimi Olgunlaşma Seviyesinin Finansal Performansa Etkisi” adlı proje kapsamında hazırlanmıştır. Bu çalışma, 2-3 Ağustos 2017 tarihleri arasında Almanya, Münih’te gerçekleştirilen, "221st International Conference on Economics and Business Management (ICEBM)” isimli konferansta sunulan "The Effect of Enterprise Risk Management Maturity Level on Financial Performance: The Turkish Case' 'başlıklı bildirinin geliştirilmiş bir versiyonudur.

** Yrd. Doç. Dr. Yasemin Ertan, Uludağ Üniversitesi, İktisadi ve İdari Bilimler Fakültesi, yasertan@uludag.edu.tr

*** Prof. Dr. Aylin Poroy Arsoy, Uludağ Üniversitesi, İktisadi ve İdari Bilimler Fakültesi, aporoy@uludag.edu.tr

**** Arş. Gör. Tuba Bora Kılınçarslan, Uludağ Üniversitesi, İktisadi ve İdari Bilimler Fakültesi,

tubabora@uludag.edu.tr
} 


\section{GIRIŞ}

Günümüzde, iş hayatında meydana gelen değişikliklerin ve rekabetin yoğunluğu nedeniyle, işletmelerin karşı karşıya kaldıkları riskler giderek artmakta, bu risklere karşılık verirken kullanılabilecek süre kısalmaktadır. Bu durum, aslında yeni bir kavram olmayan risk yönetimi kavramının önemini arttırmıştır. Risk, beklenmeyen kayıplarla karşı karşıya kalma olasılığı olarak tanımlanabilir. Risk yönetimi faaliyetlerinin etkin bir şekilde sürdürülmesi, işletmenin hem tehditlerden korunmasını sağlayarak kayıpları azaltmakta, hem de firsatları değerlendirmesini sağlayarak olası kazançları elde etmesini sağlamaktadır.

1990'lı yıllarda Amerika Birleşik Devletleri'nde yaşanan şirket skandalları, kamuoyunun dikkatinin "risk yönetimi” kavramı üzerinde odaklanmasına neden olmuştur. $\mathrm{Bu}$ skandallar sonucunda risk yönetiminde uygulanan yaklaşım da değişmiştir. 1990'lı yıllardan önce risk yönetiminde yaygın olarak silo temelli (silo-based) risk yönetimi yaklaşımı uygulanmıştır. Silo temelli risk yönetimi yaklaşımında, işletmedeki her birim, doğrudan etkilendiği ve ilgi alanları içinde bulunan risklerin yönetimine odaklanmaktadır ( Şenol ve Karaca, 2017:5). Riskler her birim tarafından ayrı ayrı yönetilmektedir. Ancak 1990'l1 yıllarda ortaya çıkan şirket skandalları risklerin bütünleşik bir şekilde yönetilmesi gerektiğini göstermiştir ve kurumsal risk yönetimi kavramı ortaya çıkmıştır.

$\mathrm{Bu}$ çalışmada kurumsal risk yönetimi sisteminin unsurları ve işletmelere sağladığı faydalar irdelenerek, Borsa İstanbul'da işlem gören imalat işletmelerinin kurumsal risk yönetimi olgunlaşma seviyeleri ile finansal performansları arasındaki ilişki incelenmiştir.

\section{KURUMSAL RISK YÖNETIMİ}

Riske ve risk yönetimine verilen önemin artmasıyla birlikte, işletmelere risk yönetimi faaliyetlerinde yardımcı olması amacıyla rehberler oluşturulmuştur. ${ }^{1}$ Bu rehberlerden en yaygın olarak kullanılanlarından biri Treadway Komisyonunu Destekleyen Kuruluşlar Komitesi (COSO) tarafından 2004 yılında yayınlanan Kurumsal Risk Yönetimi- Bütünleşik Çerçeve (Enterprise Risk Management-Integrated Framework- ERM)' dir (https://www.coso.org/Pages/default.aspx). COSO ERM' de kurumsal risk yönetimi, "kurumun yönetim kurulundan, yöneticilerinden ve diğer personellerinden etkilenen, kurumu etkileyebilecek olayları tanımlamak ve risk iştahı sınırları içinde yönetmek üzere kurum genelinde yapılandırılmış olan ve stratejilerin oluşturulmasında uygulanan, kurum hedeflerinin oluşturulmasında makul derecede güvence sağlamak amacını taşıyan bir süreç" olarak tanımlanmıştır (COSO, 2004: 4). COSO ERM’ de kurumsal risk yönetimi modeli Şekil 1 de gösterildiği gibi küp şeklindeki 3 boyutlu bir matrisle görselleştirilmiştir.

\footnotetext{
${ }^{1}$ Örneğin, COSO Kurumsal Risk Yönetimi Bütünleşik Çerçevesi, AS/ NZS 4360 Avustralya/Yeni Zelanda Risk Yönetimi Standartları, Turnbull Rehberi, ISO 31000 Risk Yönetimi Standartlar Seti....
} 


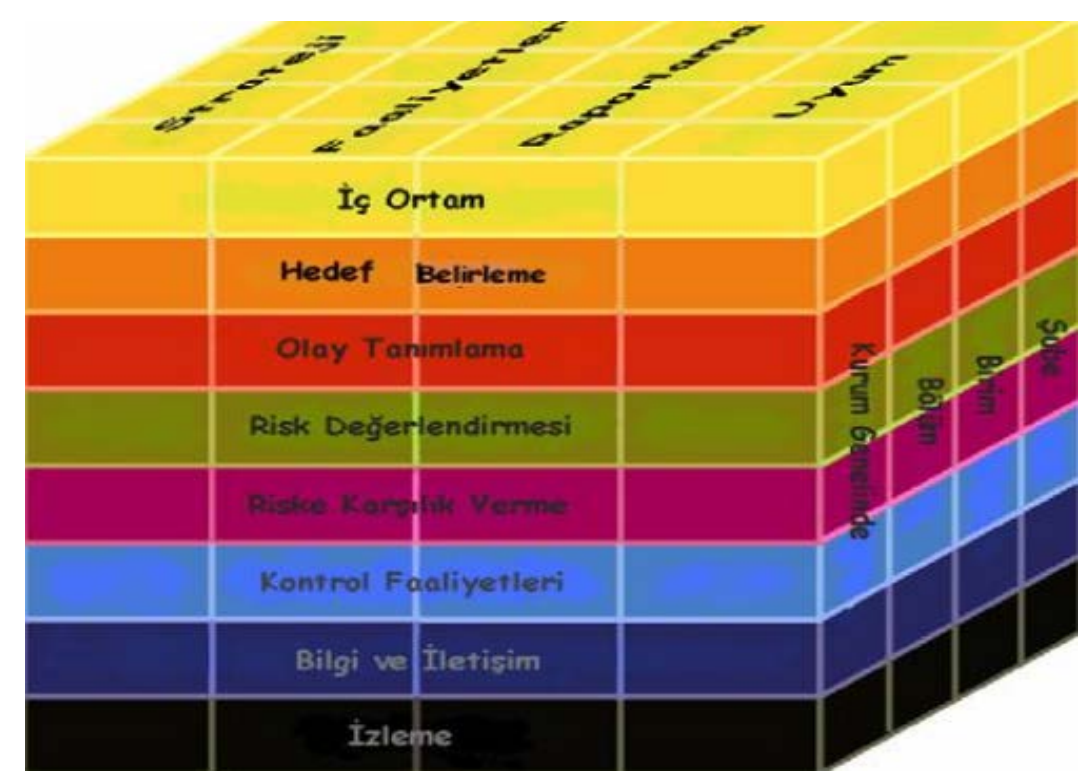

Şekil 1. COSO ERM Küpü

Kaynak: COSO, 2004: 7

Kübün ön yüzünde kurumsal risk yönetiminin bileşenleri yer almaktadır. Kurumsal risk yönetimi, iç ortam, hedef belirleme, olay tanımlama, risk değerleme, risk tutumu, kontrol faaliyetleri, bilgi- iletişim ve izleme olmak üzere birbiri ile ilişkili 8 bileşenden oluşmaktadır. Kurumsal risk yönetimi sisteminin etkinliği bu 8 bileşenin etkin bir şekilde konumlandırılmasına ve faaliyet göstermesine bağlıdır. Diğer bileşenlerin temelini oluşturan iç ortam, organizasyonun risk yönetimine karşı tavrını yansıtmaktadır. İç ortam çalışanların risk bilincini etkilemekte, kurum içerisinde disiplin sağlamakta ve altyapı oluşturmaktadır. İç ortam kurum stratejilerinin ve amaçlarının oluşturulmasında, işletme faaliyetlerinin yapılandırılmasında, risklerin tanımlanması, değerlendirilmesi ve yönetilmesinde etkili olmaktadır (COSO ERM, 2004: 27). Kurumsal risk yönetimi bileşenlerinden biri olan hedef belirleme bileşeni, olay tanımlama, risk değerlendirme ve riske karşılık verme bileşenlerinin ön koşuludur. Hedef belirleme, kurumda risklerin tanımlanmasından ve risklere uygun tutumların belirlenmesinden önce kurumun hedeflerinin belirlenmesinin gerekliliğini ifade etmektedir. Yönetim, önce amaçları belirlemeli daha sonra da bu amaçların başarılmasında etkili olacak riskleri tanımlamalı, değerlemeli ve bu riskleri yönetmek için gerekli önlemleri almalıdır (COSO ERM, 2004: 35). Kurumsal risk yönetiminin diğer bir bileşeni olan olay tanımlama bileşeni gereğince, yönetim; ortaya çıkması halinde kurumu etkileyebilecek olan potansiyel olayları tanımlamalı ve bu olayların kurum stratejilerinin uygulanmasını ve amaçlarının gerçekleştirilmesini olumlu mu yoksa olumsuz mu etkileyeceğini belirlemelidir (COSO ERM, 2004: 41). Diğer bir bileşen olan risk değerlendirilmesi, yönetimin, olayları ortaya çıkma olasılığı ve ortaya çıkması durumunda olası etkisi açısından nitel ve nicel yöntemler kullanarak değerlendirmesini ifade etmektedir (COSO ERM, 2004: 49). Riske karşılık verme bileşeni kapsamında, yönetim değerlendirilmiş olan risklere karşı verilecek olan tepkiyi belirlemektedir (COSO ERM, 2004: 55). Diğer bir kurumsal risk yönetimi 
bileşeni olan kontrol faaliyetleri, yönetimin belirlemiş olduğu risk tepkilerinin hayata geçirilmesini sağlamak üzere geliştirilmiş politikalar ve prosedürlerdir. Kontrol faaliyetleri organizasyonun tüm seviyelerinde ve fonksiyonlarında konumlandırılmalıdır (COSO ERM, 2004: 61). Bilgi ve iletişim bileşeni, çalışanların sorumluluklarını yerine getirebilmesi için ilgili bilgilerin tanımlanmasını, toplanmasını ve iletilmesini kapsar (COSO ERM, 2004: 67). İzleme bileşeni ise kurumsal risk yönetimi bileşenlerinin varlığının ve etkinliğinin değerlendirilmesidir. İzleme faaliyetleri sonucunda belirlenen aksaklıklar ve eksiklikler üst yönetime ve yönetim kuruluna bildirilir (COSO ERM, 2004: 75). Kurumsal risk yönetimi sisteminin etkin bir şekilde işlemesi için, kurum içinde tüm bu bileşenlerin etkin bir şekilde konumlandırılması ve faaliyette bulunması gerekmektedir. Kurumsal risk yönetimi bileşenlerinin işletme içindeki varlığ 1 ve etkinliği, kurumsal risk yönetiminin etkinliğini diğer bir ifade ile kurumsal risk yönetimi olgunlaşma seviyesini belirlemektedir. Şekil 1'de görüldüğü gibi, COSO ERM kübünün sağ yüzünde kurum seviyeleri yer almaktadır. Kurumsal risk yönetimi faaliyetlerinin kurum genelinde uygulanması gerekmektedir. Bununla birlikte kurumsal risk yönetimi bölüm, birim ve şube bazında da bütünleşik bir yaklaşımla uygulanmalıdır. COSO ERM kübünün üst yüzünde işletmenin amaçları yer almaktadır. Şekil 1'de görüldüğü gibi kurum amaçları stratejik amaçlar, operasyonel amaçlar, raporlama amaçları ve uyum amaçları olmak üzere dört gruba ayrılmıştır. Stratejik amaçlar, kurumun misyonunu ve vizyonunu destekleyen üst düzey amaçlardır. Operasyonel amaçlar, kaynakların etkin ve verimli kullanılmasına ilişkin amaçlardır. Raporlama amaçları, raporların güvenilirliğine ilişkin amaçlarıdır. Uyum amaçları da, kurumun işleyişinin kanun ve düzenlemelere uygun bir şekilde sürdürülmesine ilişkin amaçlardır (COSO ERM, 2004: 5)

Kurum içerisinde kurumsal risk yönetimi sisteminin bileşenlerinin her birinin, birbiriyle etkileşimli bir şekilde faaliyette bulunması ve risk yönetimi faaliyetlerinin kurum genelinde yürütülmesi durumunda, kurumsal risk yönetimi, işletmenin stratejik amaçlarına, operasyonel amaçlarına, raporlama amaçlarına ve uyum amaçlarına ulaşmasına yardımcı olacaktır.

\section{LITERATÜR ARAŞTIRMASI}

Kurumsal risk yönetiminin uygulanması işletmenin bazı finansal ve finansal olmayan kaynaklarının kullanılmasını gerektirmektedir. Doğal olarak işletmeler bu kaynak kullanımları karşılığında bazı getiriler elde etmeyi ummaktadır. Literatürde kurumsal risk yönetiminin işletmelere sağlayacağı hipotetik yararlardan bahseden birçok çalışma bulunmaktadır. Örneğin kurumsal risk yönetiminin performansı arttıracağını (Beasley vd., 2008), sermaye maliyetini azaltacağını (Nocco ve Stulz, 2006), işletmelerin daha isabetli kararlar vermelerini sağlayacağını (Nocco ve Stulz, 2006), rekabet avantajı sağlayacağını (Kommunori vd, 2016: 19), sermaye dağılımının etkinliğini arttıracağını (Myers ve Read, 2001) ifade eden çalışmalar bulunmaktadır. Bununla birlikte kurumsal risk yönetiminin 
işletmelerin finansal performansına etkisini inceleyen sınırlı sayıda ampirik çalışma bulunmaktadir.

Yapılmış olan ampirik çalışmalar incelendiğinde, bu çalışmalarda kurumsal risk yönetiminin uygulanıp uygulanmadığının ve uygulanıyorsa ne derecede etkin olduğunun belirlenmesinde genel olarak iki yöntemin uygulandığı görülmektedir. Bilindiği gibi, işletmeler, finansal raporlarında ve faaliyet raporlarında risk yönetimi uygulamalarına ilişkin bazı bilgilere yer vermektedir. Yapılmış olan çalışmaların bir kısmında işletme raporlarında veya medya haberlerinde kurumsal risk yönetimine ilişkin olarak yer alan bilgiler incelenmiş ve işletmelerin kurumsal risk yönetimi uygulayıp uygulamadıklarına karar verilmiştir. Örneğin, Hoyt ve Liebenberg (2011), sigorta şirketlerinde firma değeri ile kurumsal risk yönetimi arasındaki ilişkiyi incelemiştir. Çalışmada firma değerinin göstergesi olarak Tobin Q oranı kullanılmıştır. İşletmelerde kurumsal risk yönetimi sisteminin var olup olmadığını belirlemek için işletmenin finansal tablolarında ve işletmeyle ilgili çıkmış olan haberlerde kurumsal risk yönetimine işaret edebilecek kelimelerin (kurumsal risk yönetimi, stratejik yönetim, risk komitesi gibi) var olup olmadığı araştırılmıştır. Bu kelimelerin bulunması durumunda işletmede kurumsal risk yönetiminin uygulandığ1 aksi halde ise uygulanmadığı kabul edilmiştir. Araştırmanın sonucunda firma değeri ile kurumsal risk yönetimi arasında pozitif bir ilişki olduğu görülmüştür. Rakauskaite (2016), Litvanya'da enerji ve telekomünikasyon işletmeleri üzerinde yaptığı çalışmada, 2008 yılında yaşanan ekonomik krizden önceki ve sonraki dönemlerde, işletmelerin kurumsal risk yönetimi uygulamaları ve aktif karlılıkları arasındaki ilişkiyi incelemiştir. Çalışmada işletmelerin kurumsal risk yönetimini uygulayıp uygulamadıkları kamuya sunulan işletme raporları incelenerek belirlenmiştir. Çalışmanın sonucunda kriz öncesi dönemde işletmenin kurumsal risk yönetimini uygulaması ile aktif karlılığı arasında pozitif ve istatistiki olarak anlamlı bir ilişki olduğu ortaya konulurken, kriz sonrası dönemde istatistiki açıdan anlamlı bir ilişkinin olmadığı görülmüştür. Florio ve Leoni (2017), İtalya'daki işletmelerde kurumsal risk yönetimi ve aktif karlılığı arasındaki ilişkiyi inceledikleri çalışmalarında, kurumsal risk yönetimi uygulamalarının mevcut olup olmadığını belirlemek için kurumsal yönetim raporlarını incelemiştir. Çalışmanın sonucunda işletmelerin kurumsal risk yönetimini uygulamaları ve aktif karlılıkları arasında istatistiki olarak anlamlı pozitif bir ilişkinin olduğu ortaya konmuştur. Agustina ve Bararoh 2016 yılında Endonezya Borsa'sında işlem gören bankalar üzerinde yaptıkları çalışmada, işletmelerin yıllık raporları kullanılarak kurumsal risk yönetimini uygulayıp uygulamadıkları belirlenmiştir. Çalışmanın sonucunda kurumsal risk yönetimi uygulamaları ile işletmelerin özsermaye karlılığı arasında bir ilişki olmadığı ortaya konmuştur. Pagach and Warr (2010), çalışmalarında, risk yönetimi müdürü ile ilgili duyuru ve açıklamalar yapan işletmeleri, kurumsal risk yönetimi uygulamalarının var olduğu şirketler olarak kabul etmiş ve kurumsal risk yönetimi uygulamaları ile finansal performans arasındaki ilişkiyi değerlendirmiştir. Çalışmada işletmelerin özsermaye karlılıklarının, kurumsal risk yönetimini uyguladıkları dönemde arttı̆̆ı ortaya konmuştur. Ramlee ve Ahmed (2015), 
işletmelerin kamuya açıklanan raporlarını inceleyerek kurumsal risk yönetiminin uygulanıp uygulanmadığını belirlemiştir. Çalışmanın sonucunda işletmelerin kurumsal risk yönetimini uygulamaları ve aktif karlılıkları ve özsermaye karlılıkları arasında istatistiki olarak anlamlı olmayan negatif ilişki olduğunu ortaya koymuşlardır.

Ancak daha önce de belirtildiği gibi kurumsal risk yönetiminin 8 bileşeni bulunmaktadır. Her bir bileşenin işletmedeki varlığına ve etkinliğine göre, kurumsal risk yönetiminin olgunlaşma derecesi de değişmektedir. Dolayısıyla, işletmelerin finansal raporlarından ve faaliyet raporlarından edinilen bilgiler, işletmelerin kurumsal risk yönetimi olgunlaşma seviyelerini belirlemekte kullanılabilecek kapsamlı bilgiler sunmamaktadır. Bu noktadan hareket edilerek bazı çalışmalarda, işletmelerin kurumsal risk yönetimi olgunlaşma seviyelerini araştırmak üzere anketler geliştirilmiş ve anketlere verilen cevaplar değerlendirilerek işletmelerin kurumsal risk yönetimi olgunlaşma seviyeleri hesaplanmıştır. Örneğin Nyagah 2014 yılında Kenya'daki emeklilik şirketleri üzerinde yaptığı araştırmada, işletmelerin kurumsal risk yönetimi olgunlaşma dereceleri anket aracıllğı ile tespit etmiş, daha sonra da kurumsal risk yönetimi uygulanma seviyeleri ile finansal performansları arasındaki ilişki incelemiştir. Araştırmada finansal performansın göstergesi olarak aktif karlılık oranı ve özsermaye karlılık oranı kullanılmıştır. Araştırmanın sonucunda olay tanımlama, risk değerleme, amaç belirleme, bilgi ve iletişim bileşenleri ile finansal performans arasında negatif bir ilişki olduğu, riske karşıllk verme, iç ortam ve kontrol faaliyetleri ile finansal performans arasında pozitif bir ilişki olduğu görülmüştür.

Kurumsal risk yönetiminin etkinliğinin belirlenmesi için anket yönteminin uygulandığı diğer bir araştırma, Grace vd. (2015) tarafından yapılmıştır. Araştırmada işletmelerin kurumsal risk yönetimi uygulamaları ile aktif karlılı̆̆ arasında pozitif bir ilişki olduğunu ortaya koymuştur.

Ping ve Muthuveloo (2015), Malezya'daki 103 halka açık işletme üzerinde yaptıkları çalışmalarında, işletmelerin kurumsal risk yönetimi olgunlaşma derecelerini anket yöntemiyle belirlemiştir. Çalışmanın sonucunda kurumsal risk yönetimi uygulamaları ile firma performansı arasında pozitif bir ilişkinin bulunduğu ortaya konmuştur.

\section{METODOLOJI}

$\mathrm{Bu}$ çalışmada, kurumsal risk yönetimi olgunlaşma derecesinin işletmelerin finansal performanslarını etkileyip etkilemediğini araştırılmıştır. Bunu belirleyebilmek için öncelikle işletmelerin kurumsal risk yönetimi olgunlaşma derecelerinin ölçülmesi gerekmektedir. Kurumsal risk yönetimi ile ilgili olarak işletmenin yıllık finansal tablolarında, faaliyet raporlarında veya kurumsal yönetim raporlarında yer alan bilgiler, kurumsal risk yönetiminin olgunlaşma derecesinin belirlenmesinde yeterli olmamakta, bu değerlendirmenin yapılabilmesi için daha kapsamlı bilgilere ihtiyaç duyulmaktadır. Daha önce de bahsedildiği gibi kurumsal risk yönetiminin sekiz bileşeni vardır. Kurumsal risk yönetiminin olgunlaşma 
seviyesi (etkinliği), işletme içerisinde her bir bileşenin var olmasına ve etkin bir şekilde faaliyet göstermesine bağlıdır. Çalışmamızda, işletmelerin kurumsal risk yönetimi uygulamaları ile ilgili bilgi edinmek için anket yöntemi kullanılmıştır. Yapılan literatür araştırmasında günümüze kadar yapılan benzer çalışmalarda kullanılan kapsamlı bir ankete rastlanmamıştır. Bu nedenle COSO ERM incelenmiş ve kurumsal risk yönetimi bileşenlerinin her birinin etkinliğini tesbit etmeye yönelik ifadeler türetilerek bir anket formu oluşturulmuştur. Anket formu oluşturulduktan sonra 2'si profesör ve 1'i de banka müdürü olmak üzere 3 uzmanın incelemesine sunularak kapsam geçerliliği araştırılmıştır. Anket formu uzmanların görüşleri doğrultusunda revize edilmiştir.

Çalışmamızın ana kütlesi hisse senetleri Borsa İstanbul'da işlem gören imalat sanayi sektöründe faaliyette bulunan 182 işletmedir. Bu işletmelerin hepsine ulaşılmaya çalışılmış 58 işletmeden (182 işletmenin \%31,86’sından) geri dönüş sağlanmıştır. Anket formuna 38 firmadan yanıt alındığında güvenilirlik testi yapılmışır. Testin sonucunda Cronbach's Alpha değerinin 0,758 olduğu, diğger bir ifade ile anket formunun güvenilir olduğu görülmüştür.

Anket formu iki bölümden oluşmaktadır. İlk bölümde katılımcıların demografik özelliklerine ilişkin 3 adet açık uçlu soru, ikinci bölümde de kurumsal risk yönetimi bileşenlerinin işletmede var olup olmadığı ve etkin olup olmadığını belirlemek amacıyla 5'li likert ölçeği ile hazırlanmış 28 adet soru bulunmaktadır. 5'li likert ölçeği ile hazırlanmış sorularda (1) Kesinlikle katılmıyorum, (2) Katılmıyorum, (3) Kararsızım, (4) Katıllyorum, (5) Katılmıyorum olarak ifade edilmiştir. Anket formu EK 1'de yer almaktadır.

İşletmelerin kurumsal risk yönetimi olgunlaşma seviyesi, her bir bileşen için hazırlanmış olan sorulara verilen puanların ortalamalarının ayrı ayrı hesaplanması ve 8 bileşen için hesaplanan ortalamaların toplanması ile hesaplanmıştır. İşletmelerin kurumsal risk yönetimi olgunlaşma seviyelerinin finansal performanslarına etkisinin belirlenebilmesi için, finansal performans göstergeleri olarak aktif karlılık oranları (ROA) ve özsermaye karlılık oranları (ROE) kullanılmıştır. Finansal performans göstergesi olarak ROA' nın ve ROE' nin kullanılmasının nedeni, tanımlanmaları ve hesaplanmaları ile ilgili herhangi bir fikir ayrılığının olmamasıdır (Liargovas ve Skandalis, 2010: 185). Yapılmış olan literatür araştırması doğrultusunda, araştırmamızda kurumsal risk yönetimi olgunlaşma seviyesinin aktif karlılığına etkisinin belirlenmesinde aşağıdaki model kullanılmıştır:

$$
\mathrm{ROA}_{\mathrm{i}}=\beta_{0}+\beta_{1} \mathrm{ERM}_{\mathrm{i}}+\mathrm{SIZE}_{\mathrm{I}}+\mathrm{LEV}_{\mathrm{I}}+\varepsilon_{\mathrm{I}}
$$

Modelin bağımlı değişkeni olan ROA, işletmenin aktif karlılığını ifade etmekte olup, net karın toplam varlıklara bölünmesi ile hesaplanmıştır. ROA, işletme yönetiminin işletme varlıklarını ne kadar verimli kullandığını göstermektedir.

Modelin bağımsız değişkeni ERM, kurumsal risk yönetimi olgunlaşma seviyesidir. Kurumsal risk yönetiminin, her bir bileşen için 5'li likert ölçeği ile hazırlanmış olan anket 
sorularına verilen puanların ortalamalarının hesaplanması ve 8 bileşen için ayrı ayrı hesaplanmış olan ortalamaların toplanması ile hesaplanmıştır.

Modelin kontrol değişkenlerinden biri olan SIZE, işletme büyüklüğünü ifade etmektedir ve aktif toplamının doğal logaritması alınarak hesaplanmıştır. Büyük işletmeler, faaliyetlerini etkin bir şekilde devam ettirebilmek için gelişmiş yönetim araçlarına ihtiyaç duymaktadır. Ayrıca büyük işletmeler kurumsal risk yönetimi uygulamalarını hayata geçirebilmek için ihtiyaç duyulan fonları daha kolay temin edebilmektedir. Nitekim yapılmış olan çalışmalarda, işletmelerin büyüklükleri ve kurumsal risk yönetimi uygulamaları arasında pozitif yönlü bir ilişki olduğu diğer bir ifadeyle büyük işletmelerin, küçük işletmelere göre kurumsal risk yönetimini daha çok uyguladıkları ve kurumsal risk yönetimi olgunlaşma derecelerinin daha yüksek olduğu tesbit edilmiştir (Beasley vd., 2005; Hoyt ve Liebenberg, 2011; Önder ve Engin, 2012; Gatzert ve Martin, 2013; Farrell ve Gallegher, 2015). Diğer taraftan yapılmış olan çalışmalarda, işletme büyüklüğü ile finansal performans arasında pozitif yönlü bir ilişki olduğu ortaya konmuştur (Liargovas ve Skandalis, 2010; Doğan ve Topal, 2016 ). Modelin diğer kontrol değişkeni olan LEV, kaldıraç oranını ifade etmektedir ve işletmenin toplam borçlarının aktif toplamına bölünmesiyle hesaplanmıştır. Kaldıraç oranı işletmenin varlıklarının ne kadarını borçlarla finanse ettiğini göstermektedir. Kaldıraç oranının yüksek olması işletmenin yüksek risk altında olduğunu göstermektedir. Bu tür işletmelerde, risk yönetimi faaliyetlerine daha fazla önem verilmektedir. Dolayısıyla kaldıraç oranının yüksek olduğu işletmelerde kurumsal risk yönetimi sisteminin oluşturulması ve etkinleştirilmesi konusunda daha fazla istekli olunmaktadır (Liebenberg ve Hoyt, 2003; Önder ve Ergin, 2012; Gatzert ve Martin; 2013). Diğer taraftan kurumsal risk yönetimi uygulamaları işletmelerin daha düşük kaldıraç oranlarıyla faaliyette bulunarak, risklerini azaltmalarını sonucunu da ortaya çıkarabilir (Hoyt ve Liebenberg, 2011). Kaldıraç oranının belli bir seviyeye kadar yükselmesi işletmenin finansal performansının yüksek olması sonucunu ortaya çıkarabilir (Abor, 2005: 444; Liargovas ve Skandalis, 2010), düşük olması ise işletmenin potansiyelini tam olarak kullanamamasına ve işletmenin karlılığının da bu durumdan olumsuz yönde etkilenmesine neden olabilmektedir. İşletmelerin finansal performansları ve kurumsal risk yönetimi olgunlaşma dereceleri arasındaki ilişki işletmelerin büyüklükleri ve kaldıraç oranlarından etkilenmektedir. Bu etkilerin izole edilebilmesi için işletme büyüklügü ve kaldıraç oranları değişkenleri regresyon denklemine kontrol değişkeni olarak eklenmiştir.

Araştırmamızda özsermaye karlılığı ve kurumsal risk yönetimi olgunlaşma dereceleri arasındaki ilişkiyi belirlemek için, literatür araştırması doğrultusunda, aşağıdaki model kullanılmştır:

$$
\mathrm{ROE}_{\mathrm{i}}=\beta_{0}+\beta_{1} \mathrm{ERM}_{\mathrm{i}}+\mathrm{SIZE}_{\mathrm{I}}+\mathrm{LEV}_{\mathrm{I}}+\varepsilon_{\mathrm{I}}
$$

Modelin bağımlı değişkeni ROE, işletmelerin özsermaye karlılığını ifade etmektedir ve net karın toplam özsermayeye bölünmesi ile hesaplanmaktadır. Bu oran işletme ortakları tarafından sağlanan sermayenin ne derecede verimli bir şekilde kullanıldığını ölçmektedir 
(Gücenme Gençoğlu, 2014:103) Modelin bağımsız değişkeni olan ERM ve kontrol değişkenleri olan SIZE ve LEV hesaplanma yöntemleri ve modele dahil edilme nedenleri yukarıda geniş kapsamlı bir şekilde açıklanmaktadır.

ROA, ROE, SIZE ve LEV değerleri işletmelerin Kamu Aydınlatma Platformu tarafından yayınlanan 2016 yılına ait yıllık finansal tabloları kullanılarak hesaplanmıştır (https://www.kap.org.tr/tr/).

İşletmelerin kurumsal risk yönetimi olgunlaşma derecelerinin finansal performanslarına etkileri STATA 13 paket programı yardımıyla çoklu doğrusal regresyon analizi yöntemi kullanılarak analiz edilmiştir.

\section{BULGULAR}

\subsection{Anket Formunu Cevaplandıranların Demografik Özellikleri}

BİST’te işlem gören ve imalat endüstrisinde faaliyette bulunan 182 işletme üzerinde yapılan anket çalışmasına 58 işletmeden geri dönüş sağlanmıştır. Ankete cevap verenlerin eğitim durumu incelendiğinde \%55'inin lisans, \%45'inin de yüksek lisans mezunu olduğu görülmüştür.

Grafik 1'de anket formunu cevaplandıranların işletmelerde çalıştıkları departmanlara göre dağılımı gösterilmektedir. Şekilde de görüldüğü gibi anket formunu cevaplandıranların \%47'si finans departmanında, \%45'i muhasebe departmanında, '7'si bütçe ve raporlama departmanında ve \%2'si de sigorta ve risk departmanında çalışmaktadır.

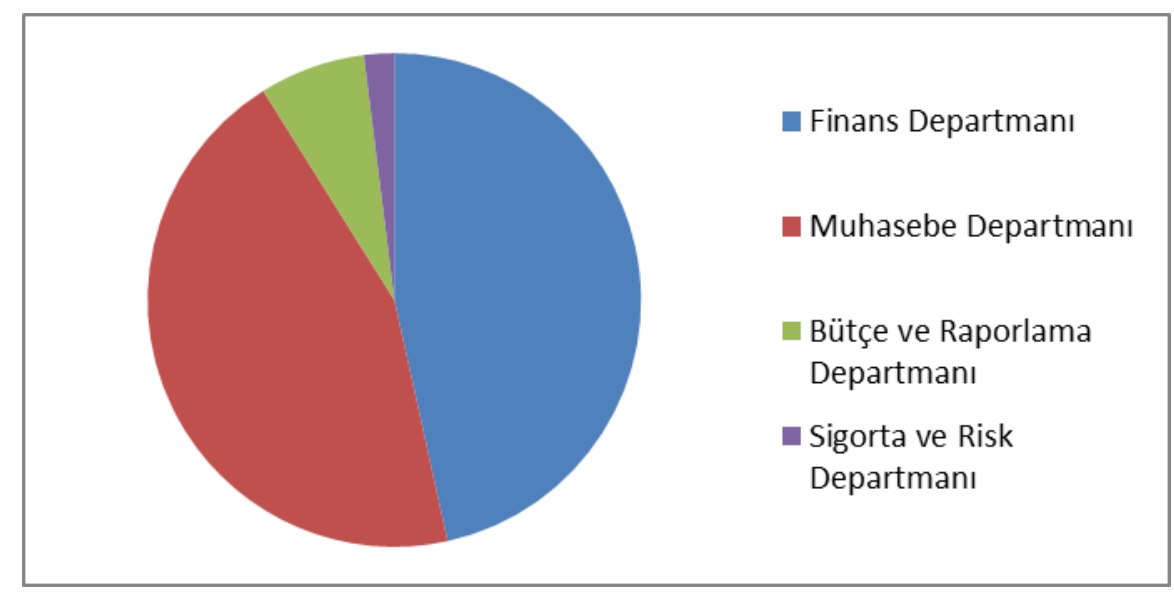

Grafik 1. Anketi Cevaplandıranların İşletmede Çalıştıkları Departman

Anket cevap verenlerin işletmedeki pozisyonları incelendiğinde, Grafik 2'den görüldüğü gibi, \%48’inin finans müdürü, \%43’ünün muhasebe müdürü, \%5’inin genel müdür yardımcısı, \%2 'sinin bütçe ve raporlama müdürü ve $\% 2$ 'sinin de sigorta ve risk müdürü olarak görev yapmaktadır. 


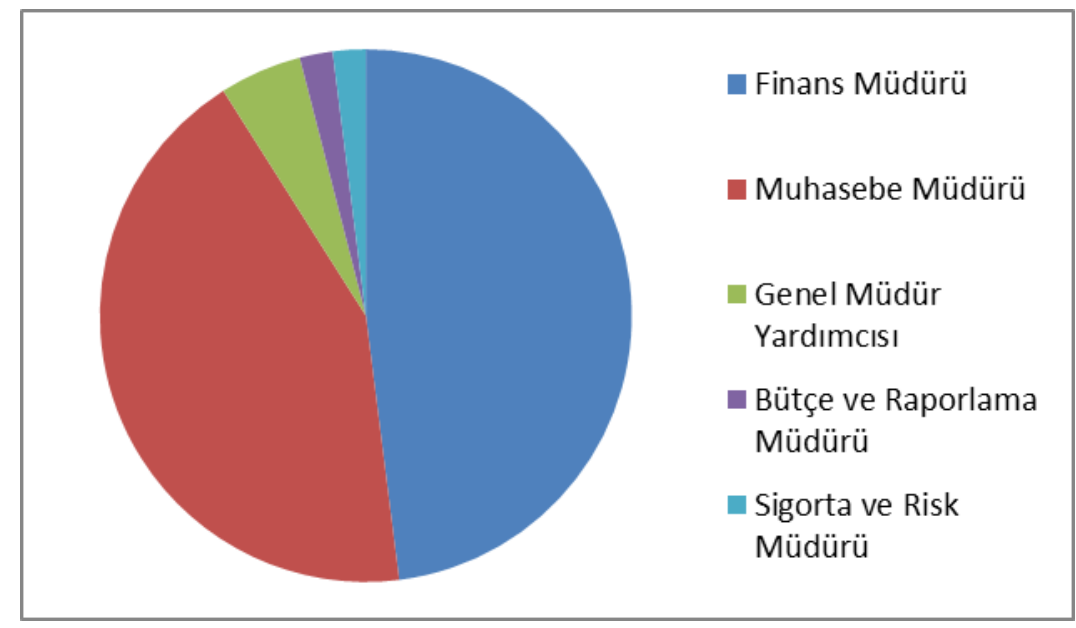

Grafik 2. Anketi Cevaplandıranların İşletmedeki Pozisyonları

Anket formunu cevaplandiranların demografik özellikleri, anket formunun işletmelerde çalışan yetkin kişiler tarafından cevaplandırıldığını göstermektedir.

\section{2. Çoklu Regresyon Analizi Bulguları}

Kurumsal risk yönetimi olgunlaşma derecesinin finansal performans üzerindeki etkisini regresyon analizi ile incelemeden önce, bağımsız değişkenler arasında çoklu doğrusal bağlantı olup olmadığının incelenmesi gerekmektedir. Tablo 1'de bağımsız değişkenler arasındaki korelasyon analizinin sonuçları görülmektedir.

Tablo 1. Bağımsız Değişkenler Arasındaki Pearson Korelasyon katsayıları

\begin{tabular}{|l|l|l|l|}
\hline & ERM & SIZE & LEV \\
\hline ERM & 1.0000 & & \\
\hline SIZE & -0.0042 & 1.0000 & \\
\hline LEV & -0.2173 & -0.0335 & 1.0000 \\
\hline
\end{tabular}

Tablo 1'de görüldüğü gibi, bağımsız değişkenler arasında çoklu doğrusal bağlantı problemi bulunmamaktadır.

Tablo 2'de kurumsal risk yönetimi olgunlaşma seviyesinin aktif karlılı̆̆ına etkisinin incelenebilmesi için yapılan çoklu doğrusal regresyon analizi sonuçları yer almaktadır. 
Tablo 2. Kurumsal Risk Yönetimi Olgunlaşma Derecesinin Aktif Karlılığına Etkisi

\begin{tabular}{|c|l|l|l|}
\hline Değişken & Katsayı & Std. Hata & Prob. \\
\hline ERM & .2801844 & .113847 & $0.017^{*}$ \\
\hline SIZE & .555073 & .3493236 & 0.118 \\
\hline LEV & .0011787 & .0038841 & 0.763 \\
\hline cons & -13.32009 & 4.780518 & 0.007 \\
\hline F (Prob $>$ F) & $.0454^{*}$ & \\
\hline \multicolumn{2}{|l}{} \\
$\mathbf{R}^{2}$ & 0.1370 \\
\hline
\end{tabular}

*\%5 anlamlılık derecesinde anlamlıdır.

Tablo 2'de görüldüğü gibi, kurumsal risk yönetimi olgunlaşma derecesinin aktif karlılığına etkisini ölçmek üzere oluşturulmuş olan model istatistiki olarak anlamlıdır (F (Prob $>\mathrm{F})=0,0454)$ ve modele dahil edilen bağımsız değişken (ERM), ve kontrol değişkenleri (SIZE,LEV), bağımlı değişkendeki (ROA) değişimin \%13,70'ini açıklayabilmektedir. Bununla birlikte aktif karlılığı ile kurumsal risk yönetimi olgunlaşma derecesi arasında istatistiki açıdan anlamlı ve pozitif bir ilişki bulunmaktadır. Diğer bir ifadeyle kurumsal risk yönetimi olgunlaşma seviyesindeki 1 birimlik artış, işletmenin aktif karlılığını 0,28 birim arttırmaktadır. Çoklu regresyon analizi sonuçlarına göre SIZE ve ROA arasında pozitif yönlü olmakla birlikte istatistiki açıdan anlamlı bir ilişkiye rastlanmamıştır. LEV ve ROA arasındaki ilişki de negatif olmakla birlikte istatistiki açıdan anlamlı değildir.

Tablo 3. Kurumsal Risk Yönetimi Olgunlaşma Derecesinin Özsermaye Karlılığına Etkisi

\begin{tabular}{|l|l|l|l|}
\hline Değişken & Katsayı & Std. Hata & Prob. \\
\hline ERM & .0349681 & .0170373 & $0.045^{*}$ \\
\hline SIZE & .0033745 & .0522765 & 0.949 \\
\hline LEV & -.088104 & .0005813 & $0.000^{*}$ \\
\hline Cons & -.9704956 & .7154079 & 0.181 \\
\hline F (Prob $>$ F) & & $0.0000^{*}$ & \\
\hline $\mathbf{R}^{2}$ & 0.9978 & \\
\hline
\end{tabular}

*\%5 anlamlılık derecesinde anlamlıdır. 
Tablo 3'de görüldüğü gibi, kurumsal risk yönetimi olgunlaşma derecesinin özsermaye karlılığına etkisini ölçmek üzere oluşturulmuş olan model istatistiki olarak anlamlıdır (F (Prob $>\mathrm{F})=0,0000)$ ve modele dahil edilen bağımsız değişken (ERM) ve kontrol değişkenleri (SIZE,LEV), bağımlı değişkendeki (ROE) değişimin \%99,78'ini açıklayabilmektedir. Bununla birlikte özsermaye karlılığı ile kurumsal risk yönetimi olgunlaşma derecesi arasında istatistiki açıdan anlamlı ve pozitif bir ilişki bulunmaktadır. Diğer bir ifadeyle kurumsal risk yönetimi olgunlaşma seviyesindeki 1 birimlik artış, işletmenin özsermaye karlılığını yaklaşık olarak 0,35 birim arttırmaktadır. Ayrıca kaldıraç derecesi ile özsermaye karlılığı arasında da istatistiki olarak anlamlı $(\mathrm{p}=0,000)$ ve negatif yönlü $(-0,088104)$ bir ilişki bulunmaktadır. Diğer bir ifade ile kaldıraç derecesinin artması, işletmelerin özsermaye karlılığını azaltmaktadır.

\section{SONUÇ}

İşletmelerin kendileri için söz konusu olan riskleri ve firsatları tespit etmeleri; stratejilerini, riskler karşısında sergileyecekleri tutum ve firsatlardan yararlanmaları için yapılması gerekenler doğrultusunda belirlemeleri, günümüzün dinamik iş yaşamı şartlarında varlıklarını sürdürebilmeleri ve rekabet üstünlüğü elde edebilmeleri için kaçınılmaz bir gerekliliktir. Bu ise kurum çapında bütünleşik bir şekilde faaliyette bulunacak etkin bir risk yönetim sisteminin oluşturulması ile mümkün olmaktadır. Bu çalışmada, kurumsal risk yönetimi olgunlaşma derecesinin Borsa İstanbul'da işlem gören imalat işletmelerinin finansal performansına etkisi incelenmiştir. Literatürdeki kurumsal risk yönetiminin işletmelere sağlayacağı yararları konu edinen birçok hipotetik çalışma bulunmakla birlikte, bu konuda yapılmış olan ampirik çalışmaların sayısı sınırlıdır.

Çalışmamızda Borsa İstanbul'da faaliyet gösteren imalat işletmelerinin kurumsal risk yönetimi olgunlaşma seviyeleri, COSO ERM'den yola çıkılarak oluşturulmuş bir anket formu yardımıyla belirlenmiş, kurumsal risk yönetimi olgunlaşma seviyelerinin işletmelerin aktif karlılıkları ve özsermaye karlılıkları üzerindeki etkisi çoklu regresyon analizi yöntemi kullanılarak analiz edilmiştir. Analiz sonuçlarına göre kurumsal risk yönetimi uygulamalarının işletmedeki etkinlik seviyesi ile aktif karlığı ve özsermaye karlılığı arasında istatistiki olarak anlamlı, pozitif bir ilişki bulunmaktadır. Diğer bir ifadeyle kurumsal risk yönetimi olgunlaşma seviyesi yüksek olan işletmelerde işletme varlıkları ve özsermaye daha verimli bir şekilde kullanılmıştır. Çalışma sonuçlarına göre kurumsal risk yönetimi uygulamaları işletmelerin finansal performansını olumlu yönde etkilemektedir.

$\mathrm{Bu}$ çalışmanın kurumsal risk yönetiminin finansal performans üzerindeki etkisini konu alan sınırlı sayıda çalışmanın bulunduğu literatüre katkı yapması beklenmektedir. Kurumsal risk yönetimi uygulamalarının hayata geçirilmesi işletmenin finansal olan ve finansal olmayan kaynaklarının kullanılmasını gerektirmektedir. Çalışmamız, bu kaynak kullanımlarının finansal performansı arttırdığını ortaya koymuştur. Dolayısıyla uygulamacıları, işletmelerin 
kurumsal risk yönetimi uygulamalarının hayata geçirmeleri ve etkinleştirmeleri doğrultusunda motive edici bir niteliktedir.

Çalışmamızın kısıtlarından biri tek bir dönem kullanılarak gerçekleştirilmesidir. Çalışmada işletmelerin yalnızca 2016 yılına ilişkin kurumsal yönetim uygulamaları ve finansal performansları incelenmiştir. Bunun nedeni kurumsal risk yönetimi sisteminin işletme içerisinde yıllar itibarı ile farklılaşabilecek olmasıdır. Diğer bir ifade ile 2016 yılında uygulanmış olan anket çalışması sonucunda hesaplanan kurumsal risk yönetimi olgunlaşma seviyesi, sistemde yapılmış olası iyileştirmeler ve değişiklikler nedeniyle, 2015 yılının kurumsal risk yönetimi uygulamalarının olgunlaşma seviyesi ile ilgili bilgi veremeyecektir. Ancak anket çalışmasının izleyen yıllarda tekrar yapılması ve işletmelerin izleyen yıllardaki kurumsal risk yönetimi olgunlaşma seviyeleri tespit edilmesiyle birlikte daha kapsamlı analizlerin yapılması mümkün olabilecektir. Diğer taraftan bu çalışmanın farklı sektörler ve daha büyük örneklemler kullanılarak geliştirilmesi kurumsal risk yönetiminin işletmelerin finansal performansı ile ilgili daha kapsamlı sonuçların elde edilmesini sağlayacaktır.

\section{KAYNAKLAR}

Abor, J. (2005), The Effect of Capital Structure on Profitability: An Empirical Analysis of Listed Firms in Ghana, The Journal of Risk Finance, Cilt 6, Say1 5, ss. 438-445.

Beasley, M. S.- Branson, B. C.- Hancock, B. V. (2008), “Rising Expectations,” Journal of Accountancy, Cilt 205, Sayı 4, ss. 44-51.

Beasley, M. S.- Clune, R.- Hermanson, D. R. (2005). Enterprise Risk Management: An Empirical Analysis of Factors Associated with the Extent of Implementation, Journal of Accounting and Public Policy, Cilt 24, Sayı 6, ss.521-531.

Committee of Sponsoring Organizations (COSO), 2004. Enterprise Risk ManagementIntegrated Framework. COSO, New York.

Doğan, M.- Topal, Y. (2016), Karlılı̆̆ı Belirleyen Finansal Faktörler: BIST’te İşlem Gören İmalat Sanayi Firmaları Üzerine Bir Araştırma, Optimum Ekonomi ve Yönetim Bilimleri Dergisi, Cilt 3, Sayı 1, ss.53-64.

Farrell, M.- Gallagher, R. (2015), The Valuation Implications of Enterprise Risk Management Maturity, The Journal of Risk and Insurance, Cilt 82, Say1 3, ss. 625-657.

Florio, C.- Leoni, G. (2017), Enterprise Risk Management And Firm Performance: The Italian Case, The British Accounting Review, Cilt 49, Sayı 1, pp. 56-74.

Gatzert, N. - Martin, M. (2013), Determinants and Value of Enterprise Risk Management: Empirical Evidence from the Literature, Working Paper, Department for Insurance Economics and Risk Management Friedrich-Alexander-University (FAU) of 
Erlangen-Nürnberg, ～https://www.vwrm.rw.fau.de/files/2016/05/ERM_2013-1123_WP.pdf (22.06.2017)

Grace, M. F.- Leverty J. T.- Phillips, R. D.- Shimpi, P. (2015), The Value of Investing in Enterprise Risk Management, The Journal of Risk and Insurence, Cilt 82, Sayı 2, ss. 289-316

Gücenme Gençoğlu, Ü. (2014), Finansal Tablolar Analizi, Aktüel Yayınları, Bursa.

Hoyt, R. E.- Liebenberg, A.P. (2011), The Value of Enterprise Risk Management, The Journal of Risk and Insurance, Cilt 78, Say1 4, ss. 795- 822.

https://www.kap.org.tr/tr/ (03.01.2017).

https://www.coso.org/Pages/default.aspx (26.02.2017)

Kommunuri, J.- Narayan, A.- Wheaton, M.- Jandug, L.- Gonuguntla, S. (2016), Firm Performance and Value Effects of Enterprise Risk Management, New Zealand Journal of Applied Business Research, Cilt 14, ss. 17-28.

Liargovas, P.G.- Skandalis, K.S., (2010), Factors Affecting Firms’ Performance: The Case of Greece, Global Business and Management Research: An International Journal, Cilt 2, Say1 2-3, ss. 184-197.

Liebenberg, A.P.- Hoyt, R.E. (2003), The Determinants of Enterprise Risk Management: Evidence from the Appointment of Chief Risk Officers, Risk Management and Insurance Review, Cilt 6, Sayı 1, ss. 37-52.

Nocco, B. W.- Stulz, R.M. (2006), Enterprise Risk Management: Theory and Practice, Journal of Applied Corporate Finance, Cilt 18, Say1 4, ss. 8-20.

Nyagah, B.K. (2014), The Effect of Enterprise Risk Management on Financial Performance of Pension Fund Management Firms in Kenya, A Research Project Submitted in Partial Fulfilment Of The Requirements For The Award Of The Degree Of Master Of Science In Finance, School Of Business, University Of Nairobi, http://chss.uonbi.ac.ke/sites/default/files/chss/BKN\%20MSC\%20PROJECT\%20\%20COC\%206.11.14.pdf (04.01.2017)

Myers, S. C.- Read, J. A. (2001), Capital Allocation for Insurance Companies, Journal of Risk and lnsurance, Cilt 68, Say1 4, ss. 545-580.

Önder, Ş.- Engin, H (2012), Determiners of Enterprise Risk Management Applications in Turkey: An Empirical Study with Logistic Regression Model on the Companies Included in ISE (Istanbul Stock Exchange). Business and Economic Horizons, Sayı 7, ss. $19-26$.

Pagach, D.- Warr, R (2010), The Effects of Enterprise Risk Management on Firm Performance,https://papers.ssrn.com/sol3/papers.cfm?abstract_id=115218(02.02.2017) 
Ping, T. A- Muthuveloo, R (2015), The Impact of Enterprise Risk Management on Firm Performance: Evidence from Malaysia, Asian Social Science; Cilt 11, Say1 22, ss.149159

Rakauskaite, A. (2016), Impact of Enterprise Risk Management on Companies’ Financial Performance and Value During Crisis: European Non-Financial Sectors- Energy and Telecommunication, A Thesis Presented to the Faculty of ISM University of Management and Economics in Partial Fulfilment of the Requirements for the Degree of Master in Financial Economics, http:/gs.elaba.lt/object/elaba:18201978/ (05.02.2017)

Ramlee, R.- Ahmed, N. (2015), Panel Data Analysis on the Effect of Establishing the Enterprise Risk Management on Firms' Performance, Proceedings of 4th European Business Research Conference 9 - 10 April 2015, Imperial College, London, https://wbiworldconpro.com/uploads/london-conference2015/finance/1427268183.pdf (16.02.2017)

Şenol, Z.- Karaca S. S. (2017), Finansal Risklerin Firma Değeri Üzerine Etkisi: Bist Örneği, Gazi İktisat ve İşletme Dergisi, Cilt 3, Sayı 1, ss.1-18. 


\section{EK 1: Çalışmada Kullanılan Anket Formu}

\section{KURUMSAL RİSK YÖNETIMI OLGUNLAŞMA DERECESI}

Sayın İlgili,

İşletmelerin kurumsal risk yönetimi olgunlaşma seviyelerinin incelenmesi amaciyla hazırladığımız ankete katılmanızı rica ediyoruz. Anket sonucunda elde edilecek bilgiler gizli tutulacak ve bilimsel araştırmalar için kullanılacaktır. Çok değerli görüşlerinizi, bilgi ve tecrübelerinizi bizimle paylaştığınız için teşekkür ederiz.

Saygilarımızla,

Prof. Dr. Aylin POROY ARSOY - Uludağ Üniversitesi Yrd. Doç. Dr. Yasemin ERTAN- Uludağ Üniversitesi Arş. Gör. Tuba BORA - Uludağ Üniversitesi

1- Eğitim düzeyiniz?
( ) Lisans
( ) Yüksek lisans
( ) Doktora
( ) Diğer.

2- Kurumda hangi departmanda çalışıyorsunuz?

3- Kurumda çalıştığınız pozisyon nedir?

4- Aşağıdaki tabloda kurumsal risk yönetimi sistemi ile ilgili ifadeler yer almaktadır. Çalıştı̆̆ınız kurumu bu ifadeleri dikkate alarak değerlendiriniz. ((1) Kesinlikle katılmıyorum, (2) Katılmıyorum, (3) Kararsızım, (4) Katılıyorum, (5) Katılmıyorum )

\begin{tabular}{|l|l|l|l|l|l|}
\hline & 1 & 2 & 3 & 4 & 5 \\
\hline $\begin{array}{l}\text { Kurumumuzda, yönetim kurulu } \\
\text { tarafından onaylanmış bir } \\
\text { kurumsal risk yönetimi politikası } \\
\text { bulunmaktadır. }\end{array}$ & & & & & \\
\hline $\begin{array}{l}\text { Kurumumuzun risk yönetim } \\
\text { politikasını tüm çalışanlar } \\
\text { tarafından bilinmektedir. }\end{array}$ & & & & & \\
\hline $\begin{array}{l}\text { Kurumumuzda, kurumsal risk } \\
\text { yönetimi kapsamında } \\
\text { sürdürülen faaliyetler yönetim } \\
\text { kurulunun değişmesi } \\
\text { durumunda kesintiye } \\
\text { uğramadan devam etmektedir. }\end{array}$ & & & & & \\
\hline $\begin{array}{l}\text { Tüm işletme çalışanları kurumsal } \\
\text { risk yönetimi sürecine aktif } \\
\text { olarak katılmaktadır. }\end{array}$ & & & & & \\
\hline
\end{tabular}




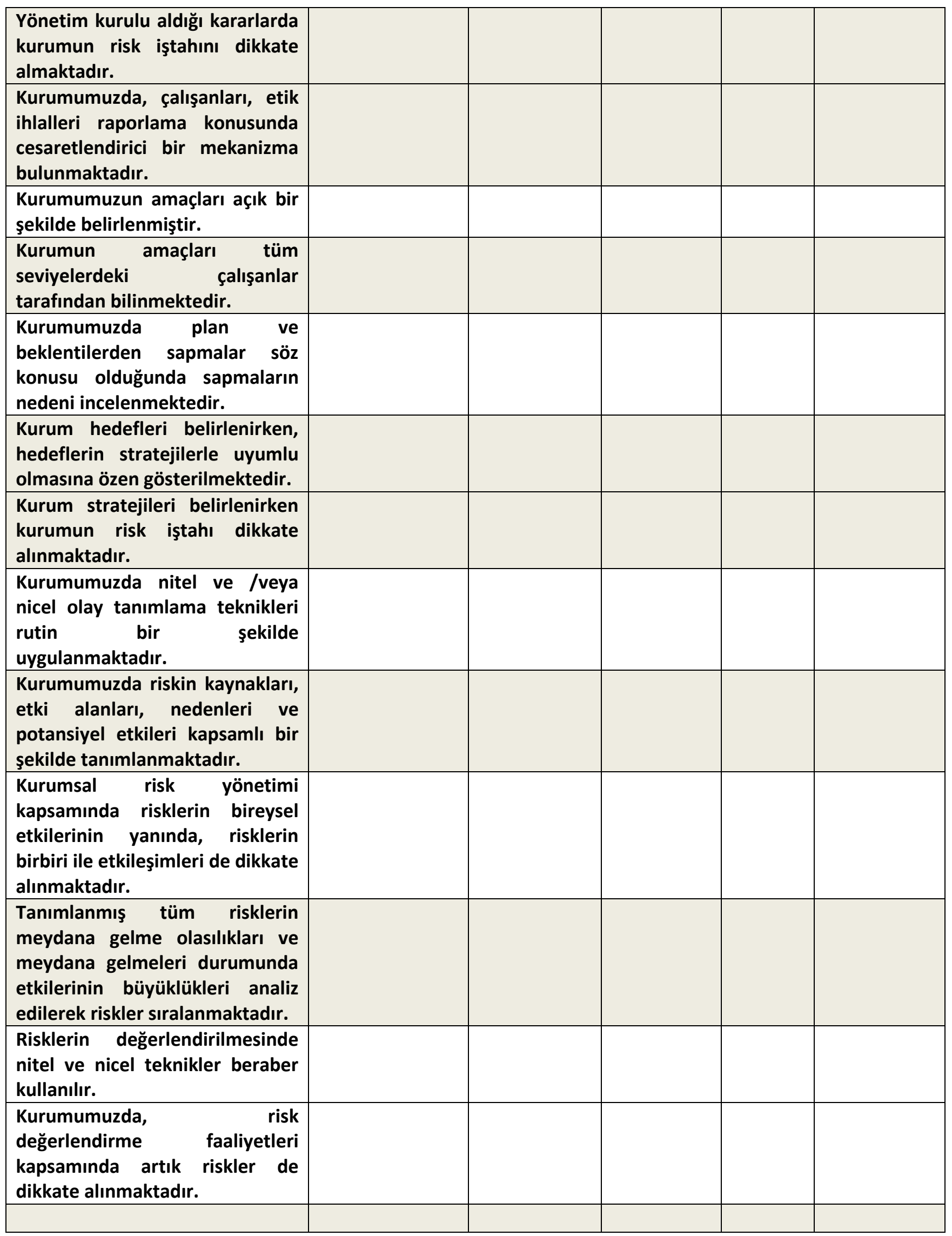




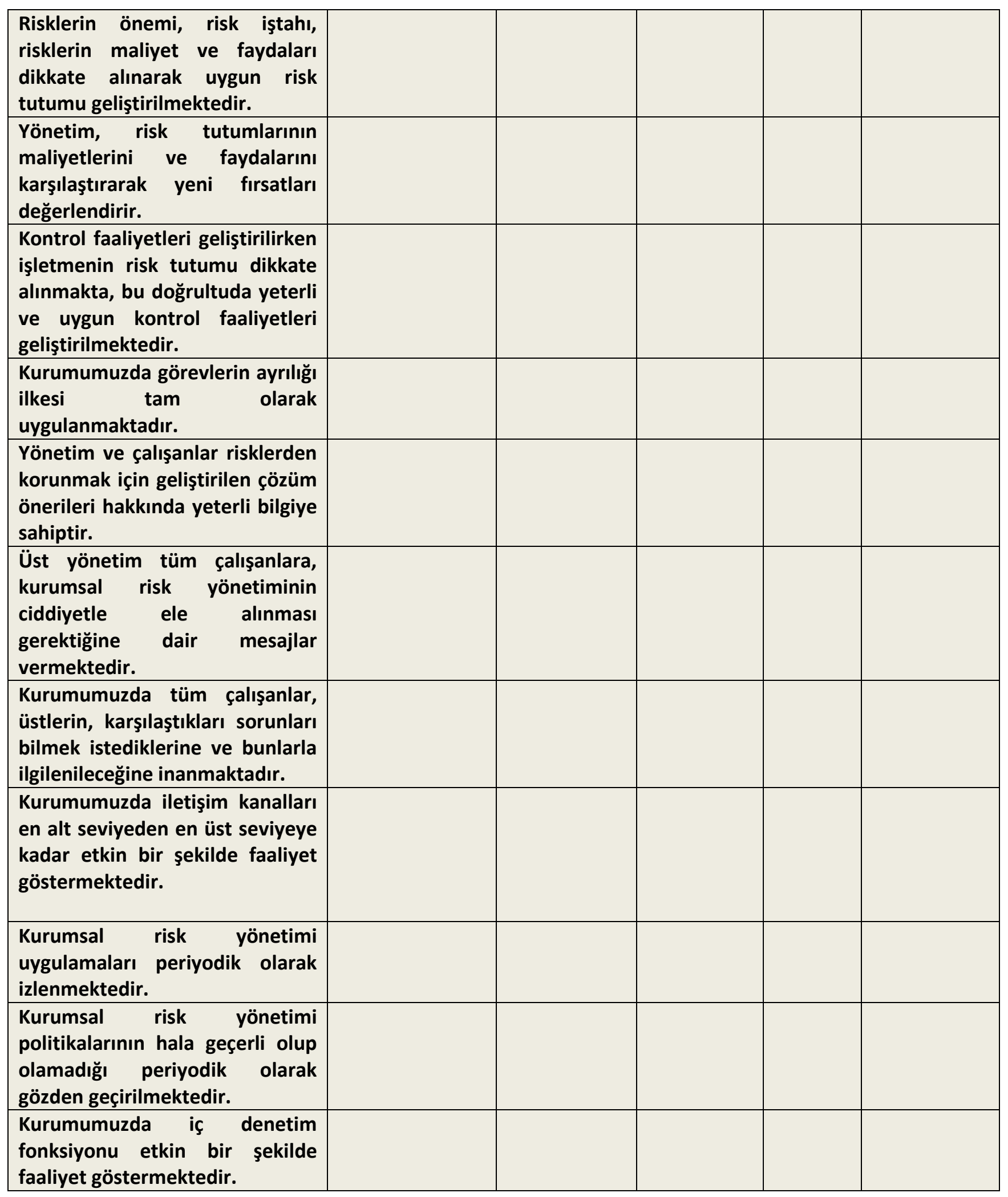

